УДК 159.964 .2

\title{
А.В. Цапенко
}

\section{АНОРЕКСИЯ КАК СПОСОБ ПОДАВЛЕНИЯ ЛИБИДО ПОДРОСТКОВ}

В статье рассматривается феноменология вторичной выгоды анорексии, а именно использование данного симптома для подавления либидо у подростков и молодых девушек с гипертрофированным внутренним и внешним религиозным запретом со стороны родителей к проявлению своей нарастающей сексуальности, обусловленной физиологией. Причины возникновения анорексии описаны во многих научных работах, но слабо раскрыты особенности влияния религиозных установок родителей на формирование анорексии у подростков. В статье раскрываются психологические механизмы (смещение агрессии и вторичные выгоды), которые удерживают проблему и делают невозможным достижение результата в терапии недуга. Представлена выборка из обратившихся в психологический центр за помощью родителей подростков и молодых людей, страдающих анорексией и при этом имеющих сильные религиозные убеждения, что может влиять на возникновение и удержание негативного симптома при определенных обстоятельствах. Для успешной терапии и профилактики анорексии установлены обстоятельства, которые могут способствовать возникновению анорексии у подростков из семей с сильной религиозной направленностью. Ключевым моментом в психоаналитической работе с девушками явилось временное отключение их от религиозных убеждений до сознательного выбора в будущем. Это служит необходимым условием для эффективного решения проблемы, так как имеющиеся сомнения по поводу правильности/неправильности поведения создают определенное невротическое давление и могут привести к таким последствиям, как анорексия.

Ключевые слова: расстройство пищевого поведения, анорексия, эдипальный конфликт, подростковое либидо, религиозные семейные установки, подростки.

DOI: $10.35634 / 2412-9550-2021-31-2-186-198$

\section{Введение}

Существует значительный объем литературы, сообщающей об отрицательной связи между религиозностью и психиатрическими симптомами. Однако в контексте расстройств пищевого поведения эта взаимосвязь может быть обратной.

Понятие «нервная анорекси́я» (др.-греч. $\dot{\alpha}-$ «без-, не-» + ő $\rho \varepsilon \xi ı$ «позыв к еде») определяется как расстройство, синдром, заключающийся в полном отсутствии аппетита при объективной потребности организма в питании [15]. Об анорексии как способе улучшения своей внешности сказано много, но в лечении этого заболевания больших успехов не достигнуто [27-32]. Заключение, которое делают ученые, сводится к тому, что психологической причиной нежелания употреблять достаточно пищи пациентами является неудовлетворенность своим внешним видом, нарушения в Я-концепции, смысложизненных ориентациях $[1 ; 2 ; 4 ; 11 ; 34]$. Медицинские концепции анорексии склоняются к тому, что корнем проблемы являются физиологические и генетические предпосылки. Так, доказано, что при наличии родственника, страдающего нервной анорксией, шансы заболеть увеличиваются в 8 раз [15; 24$]$.

Мы обратимся к глубинным психологическим причинам анорексии, связанным с внутренними психическими процессами, а именно с объектами в бессознательном. В своем исследовании мы будем исходить из объектной концепции в объяснении механизмов анорексии, описанных многими авторами, придерживающимися психоаналитической модели объектных отношений. Теория объектных отношений базируется на психодинамической концепции 3. Фрейда и является своего рода ее надстройкой, но в отличие от классического психоанализа вектор влечений смещается с инстинкта и принципа удовольствия к поиску значимого объекта [21]. То есть либидо направлено не на удовольствие, а на объект привязанности, которым чаще всего является человек.

Центральное место отводится потребности субъекта быть связанным с так называемым хорошим объектом и развязаться с плохими. Р. Фэйрберн [22] (совместно с М. Кляйн [10] и Д. Винникоттом [5]) является одним из основоположников теории объектных отношений, в которой развитие личности основывается на переживаниях ребенка о взаимоотношениях внутри семейного окружения. Внешние объекты становятся внутренними (с субъективным восприятием их качеств) [10]. Интенсивность переживания подобного отношения к объектам может влиять на внешнее поведение субъекта. Противопоставления и разделение объектов на «плохие» и «хорошие» начинаются с младенчества, 
когда частичные объекты (материнская грудь) воспринимаются амбивалентно - одна грудь «добрая» (хорошая), другая «злая» (плохая) [10;26]. Исходя из теории объектных отношений, мы можем увидеть связь между конфликтом с значимым окружением и возникновением анорексии.

При анорексии тело тоже может восприниматься человеком как «хороший» или «плохой» объект. Если мать девушки считается для нее плохим объектом (безучастным, контролирующим, злым, лживым, ненавидящим, ненавистным), то за счет идентификации с матерью агрессия с материнского объекта смещается на собственное тело.

Добавим, что еда может достигать различных степеней символизации, от простого суррогатного заменителя материнского объекта до качества переходного объекта - существо «не-я/не-мать». А также вплоть до символического представления, где тело и еда выступают объектами при анорексии. То есть внутренние переживания, связанные с объектами в бессознательном, проецируются на внешние символические объекты, такие как тело и продукты. Учитывая возможность наличия троллинга над симптомом, различные фантазии часто связаны с едой, которая соответствует «хорошим» и «плохим» объектам. Такие патологические переходные объекты, к которым мы причисляем пищу при булимии либо рвоту при анорексии, выступают попытками перенести задачи символических объектов на замещающие объекты внешнего мира.

Рассмотрим приложение вышеизложенных идей к контексту исследования. Попытки замещения у подростков обычно сопровождают нарушенные отношения с родителями. Психический внутренний мир подростков с проявлениями анорексии слабо структурирован либо поврежден ввиду несоответствия религиозных догм родителей и их поведения. Функция еды при анорексии заключается в демонстративном симптоме и ассоциируется с преувеличенным протестным настроем подросткового возраста $[3 ; 27 ; 31]$.

Отказ от еды может происходить из-за состояния напряжения, одиночества, ощущения давления, а также из-за чувства превосходства. Анорексия у подростков и молодых людей характеризуется постоянным контролем массы тела [3; 31]. Внешняя еда превращается в чужеродный объект, сливается с материнским злом. В прежние времена рвота была олицетворена как избавление от сатаны, которого нужно было изгнать, активно вызвать рвоту, прежде чем само тело станет злым [33]. Делая выводы, мы можем заключить, что при анорексии тело воспринимается или используется как объект, а не как угроза, когда оно становится слишком тяжелым, слишком толстым, слишком женственным, слишком похожим на мать, как хороший объект.

Из-за часто повторяющейся последовательности приступов обжорства и рвоты тело выполняет функцию настоящего, а не критического материнского объекта, например, как объект, связанный с анорексией. Нервную анорексию следует понимать как иллюзорные попытки и способ самоутвердиться перед родителями.

Функции еды и собственного тела при анорексии понимаются как репрезентации «хороших» и «плохих» материнских объектов. При нервной анорексии тело в состоянии недостаточного веса - это хороший материнский объект (не-мать) [25]. Таким образом, анорексия понимается как попытка справиться со страхом перед слиянием с матерью, а также со страхом разлуки с ней, который может проявиться в подростковом возрасте.

Однако при всем многообразии исследований целые пласты психической жизни, скрывающие причину заболевания, остаются малоизученными. К их числу относятся и специфика семейных отношений в религиозных семьях и их влияние на отношение к пище и формирование анорексии. Несмотря на то что религиозная идентичность сегодня не относится к числу компонентов социальной идентичности современных россиян [13], количество религиозных семей и людей, которые считают, что религия помогает им в повседневной жизни, неуклонно растет [6; 23], в связи с чем повышается актуальность изучения данного аспекта проблематики анорексии.

Исследуя вопрос влияния христианского уклада в семье на ее целостность и прочность взаимоотношений между ее членами, можно прийти к однозначному выводу о том, что семьи, исповедующие одну веру и участвующие в одних традициях и церемониях, довольно крепкие [8].

Из числа исследований, посвященных взаимосвязи религиозности и качества семейных отношений, является интересным исследование в рамках диссертации Д.М. Чумаковой [23]. В работе рассматриваются семьи, принадлежащие к Русской Православной церкви. Общий объем выборки испытуемых - 358 человек. Цель данного исследования заключалась также в выявлении взаимосвязи религиозности личности с удовлетворенностью супругов различными сферами семейной жизни. Согласно 
результатам данного исследования, испытуемые с высокими показателями религиозности личности проявляют себя в семейном социальном взаимодействии как более удовлетворенные семейной жизнью, менее подверженные эмоциональному стрессу и реже наказывающие своих детей. Религиозность увеличивает субъективное благополучие, снижает эмоциональный стресс и оптимизирует социальное взаимодействие в семье.

По результатам современных исследований, религиозные семьи отличаются от нерелигиозных в следующих аспектах $[6 ; 23]$ :

- члены религиозных семей проявляют себя в социальном взаимодействии как более удовлетворенные семейной жизнью, менее подверженные эмоциональному стрессу;

- в религиозной семье родители реже наказывают своих детей (семьи в контексте православия, отношение матерей в исламских семьях);

- религиозность увеличивает субъективное благополучие, снижает эмоциональный стресс и оптимизирует социальное взаимодействие в семье;

- чем больше выражена религиозность в семье, тем меньше количество разводов;

- семья сохраняет свой значимый статус как источник религиозных ценностей, при том что данная значимость может быть разной в контексте различных религий [8].

Практически не изучены религиозные семьи протестантов в России, хотя протестантизм представляет собой одну из христианских конфессий. Соответственно, изучение семейных отношений в протестантских семьях является перспективным направлением в изучении религиозных семей [23].

Учитывая актуальность темы и ее проблематичность, была сформулирована цель нашего исследования: установить прямую или косвенную взаимосвязь между возникновением и удержанием анорексии подростков и молодых девушек из семей с религиозным укладом. Были сформулированы задачи нашего исследования:

- выявить утилизацию отвращения девушек в возрасте от 13 лет до 21 года к людям через защитный механизм «смещение» при помощи еды;

- выявить взаимосвязь между отказом от еды и степенью чувства вины за сексуальные импульсы;

- выяснить, есть ли взаимосвязь между религиозным укладом семьи и возникновением анорексии у девушек в возрасте от 13 лет до 21 года;

- если таковая связь имеется, то выяснить, какие условия отвечают за возникновение анорексии у подростка из религиозной семьи;

- выявить, могут ли интеллектуальные особенности влиять на возникновение анорексии у девушек из религиозных семей; если да, то какие.

\section{Организация и методика исследования}

Выборку исследования составили 32 девушки в возрасте от 13 лет до 21 года, обратившиеся за помощью в «Центр психологической безопасности». Большая часть из них - из семей с сильными религиозными традициями. Нельзя утверждать, что религиозные убеждения родителей влияют на возникновение негативного симптома, который мы рассматриваем в этой статье, но интересно, в каких случаях и при каких условиях они могут иметь отношение к этому вопросу. Нельзя говорить о возможном влиянии постулатов любой религии на возникновение нарушений пищевого поведения, так как в Центр обращались только представители христианской веры различных ответвлений.

Исследование осуществлялось в период с марта 2018 года по сентябрь 2020 года.

\section{Методики исследования}

1. Разработанное автором структурированное психоаналитическое интервью, состоящее из 25 вопросов, направленных на выявление взаимосвязи анорексии с религиозными установками в семье, на основе которых строится воспитание респонденток и общий уклад жизни.

Помимо формальной части (пол, возраст, вес, рост), интервью условно имеет 4 раздела.

Первая часть (с 1 по 6 вопрос) напрямую посвящена вопросу анорексии девушки и выясняет, были ли у нее родственники с данной проблемой, как давно началось снижение веса, какое событие, по ее мнению, послужило причиной, проходила ли она лечение по этому поводу, какие чувства и эмоции она испытывает при долгом отказе от еды или вызове рвоты.

Второй блок вопросов (с 9 по 16) отражает характер взаимоотношений в семье и степень религиозности согласно восприятию самой девушки. Сюда включены сведения о составе семьи, межличностных отношениях ее членов, об отношении к религии (какая вера исповедуется, как часто посе- 
щают церковь, нравится ли ей туда ходить, разделяет ли она религиозные взгляды родителей, что для нее значит религия и вера в Бога (Всевышнего) и т. д.).

Третья часть (7-8 и 16-19 вопросы) направлена на определение фактов проявления сексуальных импульсов у девушки-подростка. Здесь участницам предстояло рассказать, имеет ли место в их жизни самоудовлетворение (с какого возраста, были ли случаи, когда их застукали за этим занятием, какие чувства они испытали при этом), каково отношение к сексуальной сфере в их семье, что об этом говорят родители, возникали ли у девушек сексуальные импульсы, за которые потом они испытывали чувство стыда.

Четвертый раздел (с 20 по 25 вопрос) посвящен детско-родительским взаимоотношениям и выясняет, как часто и за что девушка злится на своих родителей, каким способом она это проявляет или сдерживает, насколько она верит родителям и тем ценностям, которые они транслируют, возникало ли желание уйти из дома и почему.

Такое структурирование беседы направлено на выяснение жизненных аспектов подростка, раскрывающих обстоятельства поставленных нами задач, и позволяет наиболее полно посмотреть на межличностные отношения в семье и оценить возможные связи анорексии девушки с религиозными установками родителей, в соответствии с которыми устроен уклад семьи и воспитание девушки.

2. Тест Равена.

В контексте данного исследования, интересен показатель интеллектуальных особенностей респонденток и вероятность их влияния на возможную взаимосвязь между анорексией подростков и религиозными убеждениями членов семьи.

\section{Результаты исследования}

В качестве основных факторов, относящихся к религиозным установкам родителей, способных оказать влияние на возникновение и удержание у девушек-подростков анорексии, мы выделяем убеждения по отношению к сексуальной сфере и взаимодействию с окружающими. Среди них проповедание целомудрия, скромности, греховности проявлений сексуальности и агрессии (в том числе в помыслах), сдержанности, доброты, почитания старших.

Наличие этих постулатов в семьях было подтверждено в ходе предварительной беседы с родителями девушек, обратившихся за помощью (табл. 1).

Таблица 1

Наличие религиозных убеждений, транслируемых родителями своим дочерям, страдающим анорексией

\begin{tabular}{|c|l|c|}
\hline$№$ п/п & \multicolumn{1}{|c|}{ Убеждение } & Частота встречаемости, в \% \\
\hline 1 & Целомудрие & 97 \\
\hline 2 & Секс - это грязно, стыдно & 87 \\
\hline 3 & Нужно быть скромной, сдержанной & 100 \\
\hline 4 & Добродетель - одна из главных ценностей человека & 97 \\
\hline 5 & Злость - это грех & 100 \\
\hline 6 & Старших нужно почитать и слушаться во всем & 94 \\
\hline
\end{tabular}

Анализ ответов по вопроснику интервью выявил следующие особенности возникновения и течения анорексии у подростков женского пола и молодых девушек в семьях с религиозным укладом.

$18,5 \%$ респонденток в качестве запускающего механизма анорексии определили ситуации, когда они стали невольными свидетелями «греховности» своих родителей (секс, наличие запретных видео, атрибутов и т. п.) на фоне пропагандируемого целомудрия и добродетели.

У 28 \% девушек расстройства пищевого поведения в виде анорексии и ее первых признаков начались после случаев возникновения сексуального влечения и его подавления как непонятного состояния, а также после испытанных вины и страха за появление запретных ощущений, в двух случаях - сразу после самоудовлетворения возникшего желания (рис. 1).

Данный факт можно рассматривать как свидетельство наличия у них гипертрофированного чувства вины за сексуальные импульсы, составляющие, по нашему мнению, основу образования анорексии подростков. 


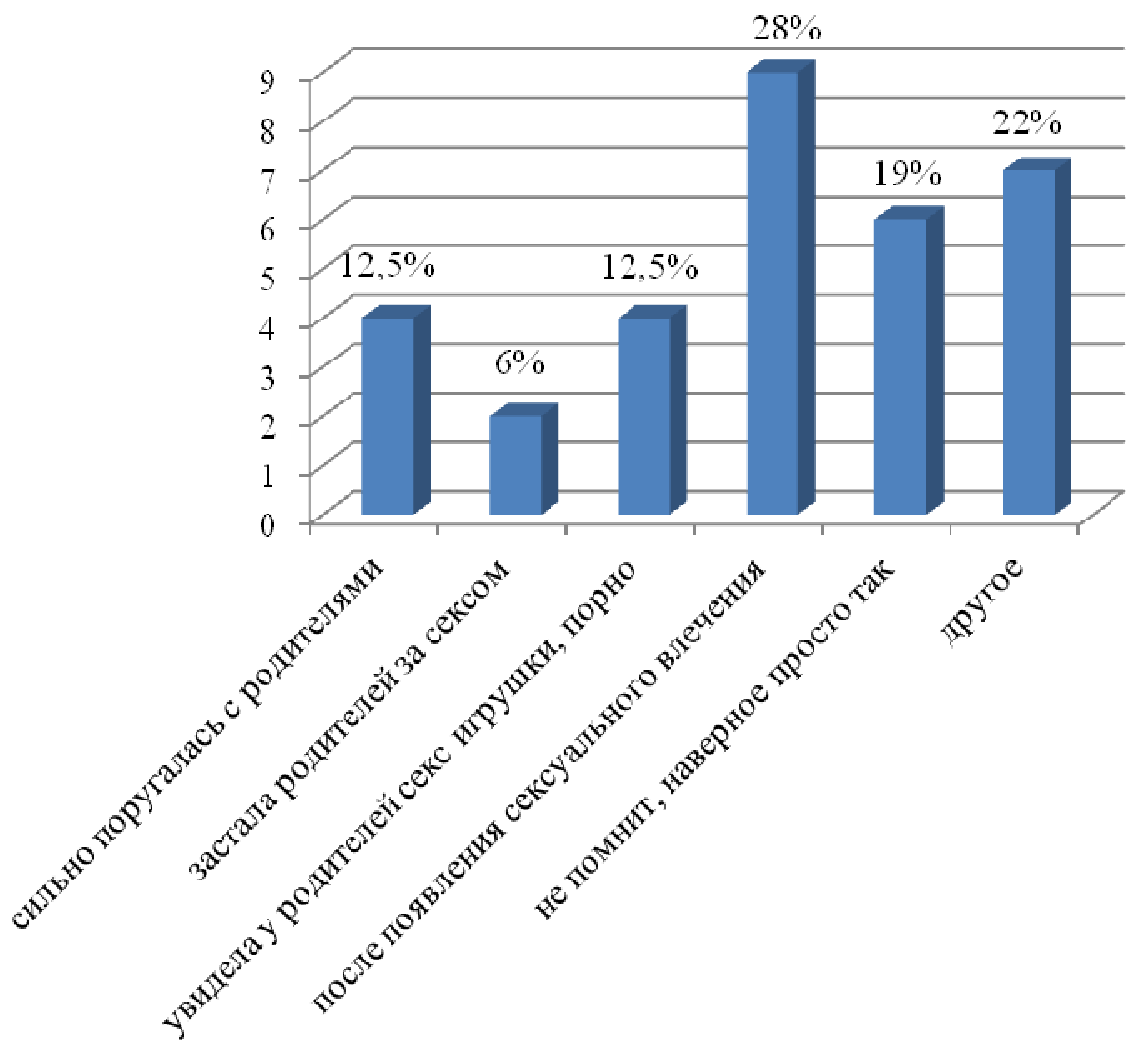

Рис. 1. Ситуация-повод появления анорексии у девушек из религиозных семей

Невозможность вспомнить, что послужило толчком ограничения себя в еде у 19 \% респонденток, может демонстрировать механизм вытеснения нежелательных воспоминаний, в том числе связанных с проявлением либидо.

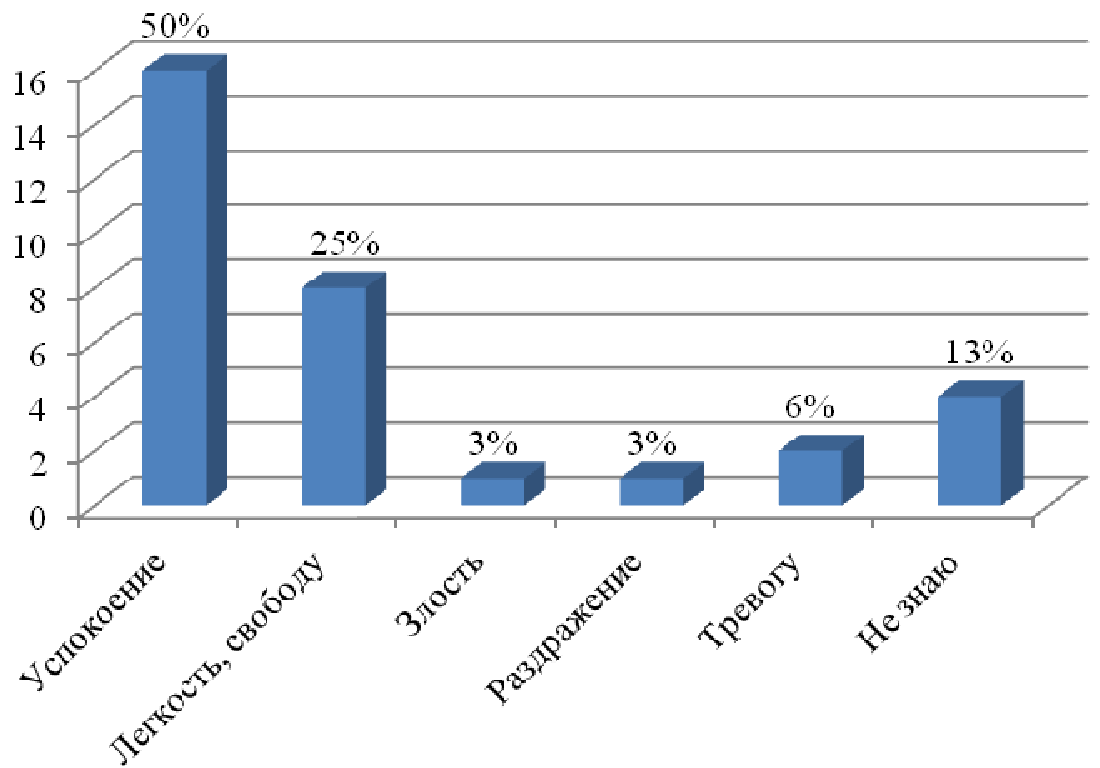

Рис. 2. Чувства, которые испытывают девушки-подростки из религиозных семей при длительном отказе от еды

В качестве единичных случаев девушки отмечали, что потеря аппетита и отвращение к еде у них возникли на фоне любовных переживаний, после конфликта с одноклассниками, ссоры с подругой и другое. В силу незначительности их частоты указанные случаи в рамках предмета исследования будут восприниматься нами как дополнительные данные. 
При определении влияния количества потребляемой пищи на вес респонденток 94 \% указали на прямую взаимосвязь съедаемого объема на массу их тела. Что служит для многих из них подтверждением правильности выбора в пользу ограничения себя в еде.

Что касается чувств, которые испытывают подростки и молодые девушки при длительном отказе от еды или ограничениях в еде, то большей части присущи положительные ощущения, такие как успокоение, легкость и свобода (рис. 2). Данные ответы указывают на избавление от существующего чувства вины и обретение желанного внутреннего спокойствия за счет физического истощения, перекрывающего сексуальное влечение.

Указанное предположение подтверждается тем, что практически все эти девушки (62 \%) имеют случаи мастурбации. Из 20 человек, занимающихся самоудовлетворением периодически или единожды, у $35 \%$ первый опыт приходится на возраст 6-8 лет, у 25\% - на 9-10 лет. Такой ранний интерес к своему телу и противоположному полу, а также частые мысли об этом и возникающие ощущения в теле (даже при недопущении мастурбации) свидетельствуют о повышенной сексуальности девушек.

При этом в 87 \% семей тема секса является запретной, а проявление сексуальности - грязным и постыдным. Таким образом, подростки находятся в ситуации сильного внутреннего стресса в следствие подавления нарастающего либидо и непонимания, каким допустимым способом можно удовлетворить возникающее сексуальное желание.

На вопрос «Были ли у вас сексуальные импульсы, которые вы не могли в себе интерпретировать как сексуальные и потом испытывали за это чувство стыда?» $44 \%$ респонденток ответили утвердительно. Тех, кто не понял вопрос или не захотел на него отвечать, оказалось 34 \% (рис. 3). В данном случае у большинства это можно расценивать как попытку уйти от ответа в связи с желанием вытеснить данные факты из своей памяти.

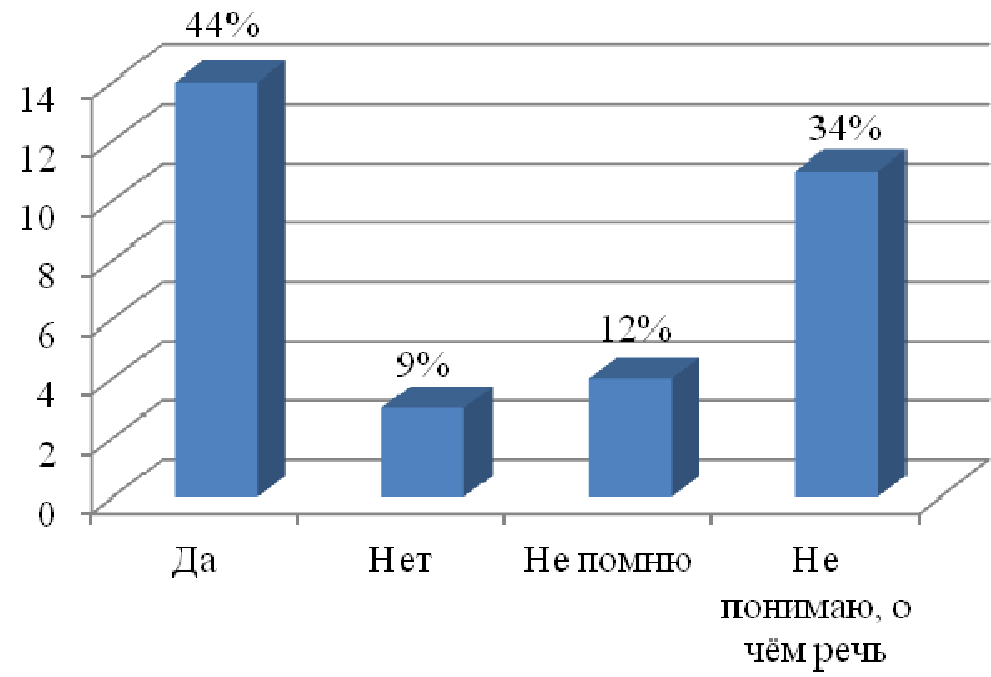

Рис. 3. Ответы на вопрос «Были ли у вас сексуальные импульсы, которые вы не могли в себе интерпретировать как сексуальные и потом испытывали за это чувство стыда?»

Говоря о ценностях, которые родители транслируют своим детям в исследуемой группе, на первое место вышли дети и семья (рис. 4) как высшие дары, данные человеку.

При этом $19 \%$ подростков убеждены, что их родители врут в вопросе своих ценностей, и $16 \%$ считают, что они скорее врут, чем не врут. По их мнению, родители лишь демонстрируют данные ценности, а на самом деле они двуличны и для них важны более низменные блага и удовольствия. В первую очередь такого мнения придерживаются те, кто уличил своих родителей в «греховности». И все же большая часть (66 \%) верит родителям.

Выясняя наличие агрессии подростков и молодых девушек по отношению к своим родителям, большинство $(37,5 \%)$ признались, что часто злятся на них, $31 \%$ - иногда, почти никогда не злятся $19 \%$, и совсем не испытывает такого чувства $12,5 \%$ респондентов.

Из тех, у кого бывает злость к родителям, проявляют ее преимущественно вербально (39 \%), хотя есть и те, кто используют физическую агрессию, в том числе бросание предметов (рис. 5). 

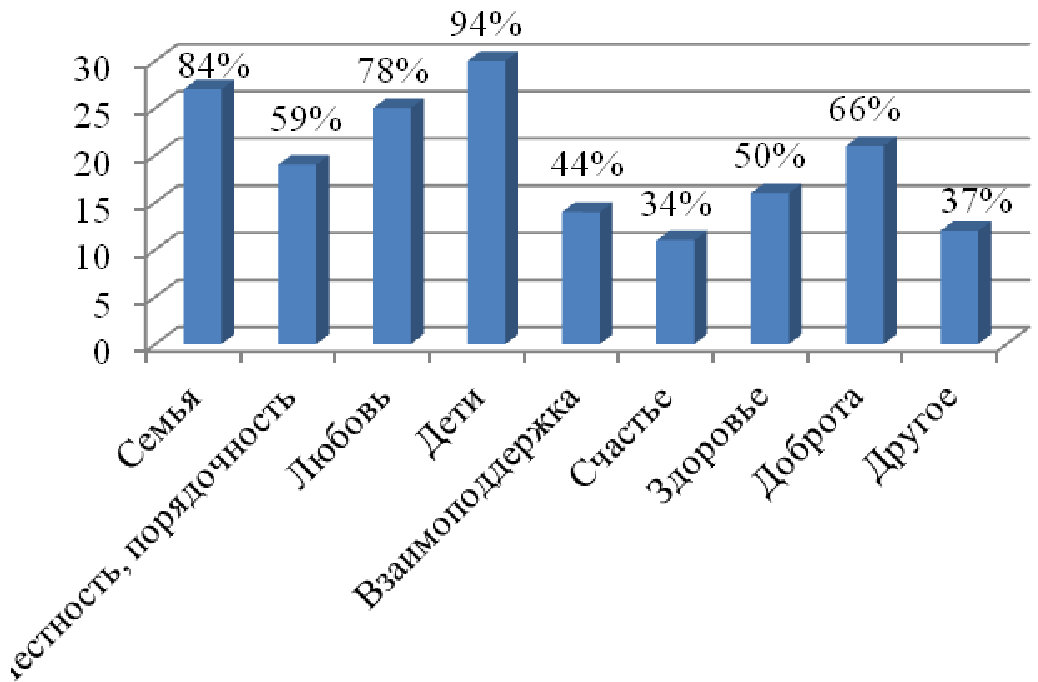

Рис. 4. Самые главные ценности родителей в религиозных семьях

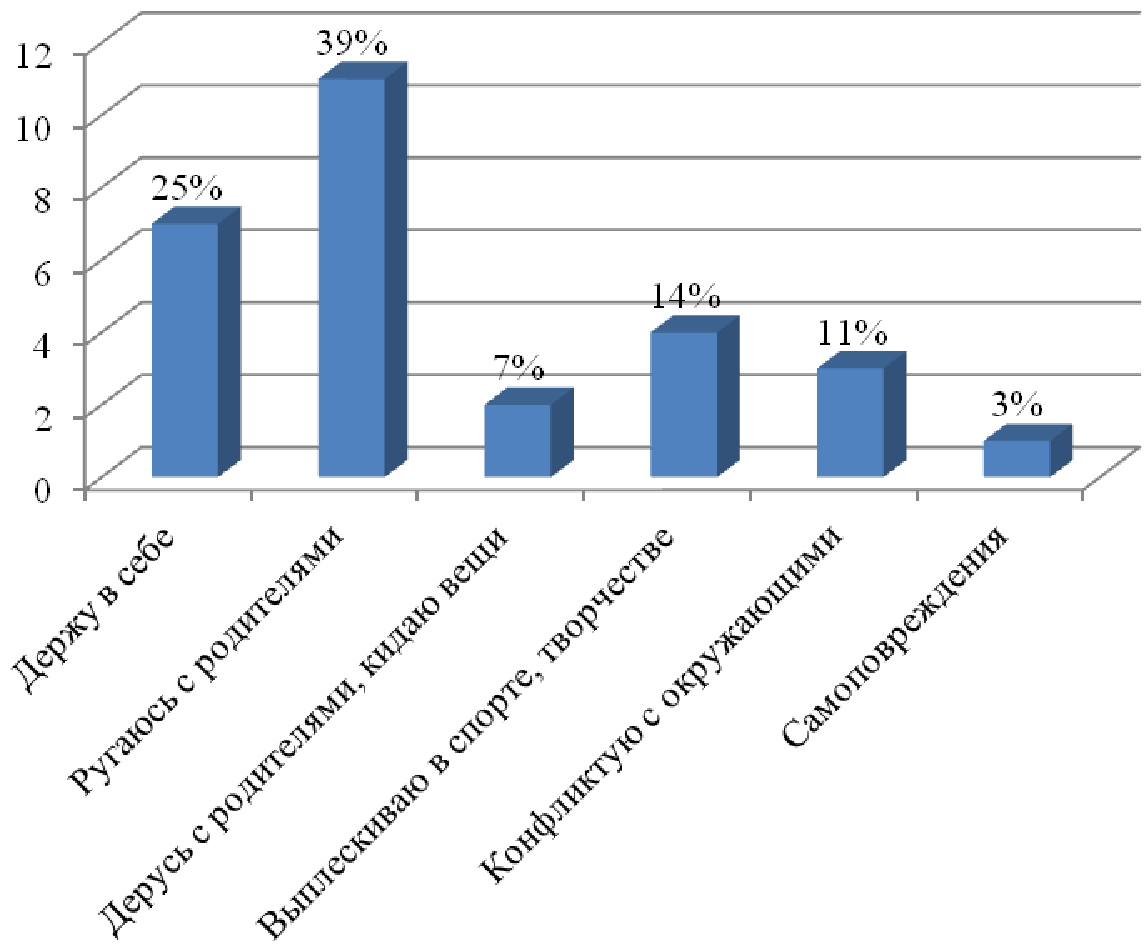

Рис. 5. Проявление агрессии подростков и молодых девушек по отношению к родителям в религиозных семьях

С целью определения возможной взаимосвязи интеллектуальных способностей с анорексией участницам исследования было предложено пройти тест Равена. Результаты показали, что у большей части подростков и молодых девушек (66 \%) уровень интеллекта - в диапазоне от 110 до 119 баллов, что соответствует уровню выше среднего (рис. 6).

После проведенного теста IQ и развернутого психоаналитического интервью с подростками и молодыми девушками были приглашены их родители, где им предоставили план психокоррекционных мероприятий и наше видение о причинах проблемы.

Из 32 семей, придерживающихся христианской религиозной доктрины, которые обратились в наш Центр за помощью в избавлении от анорексии их дочерей, 19 отказались от услуг Центра из-за необходимости обсуждения религиозных тем во время психотерапии, 6 девушек самостоятельно от- 
казались от терапии из-за того, что сразу допустили возможную обусловленность причины проблемы религиозной направленностью, и, как следствие, возможность потерять веру. Это сделало бы невозможным, с их слов, комфортное взаимодействие с родственниками, поэтому анорексия ими рассматривается как наименьшее зло. Четверо проявили любопытство и с разрешения родителей прошли успешную терапию, где удалось договориться отложить вопрос погружения в религию до более зрелого возраста, что дало возможность проведения психоаналитической терапии. Три девушки проявляли признаки религиозного бреда. Им была дана рекомендация обращения к психиатру.

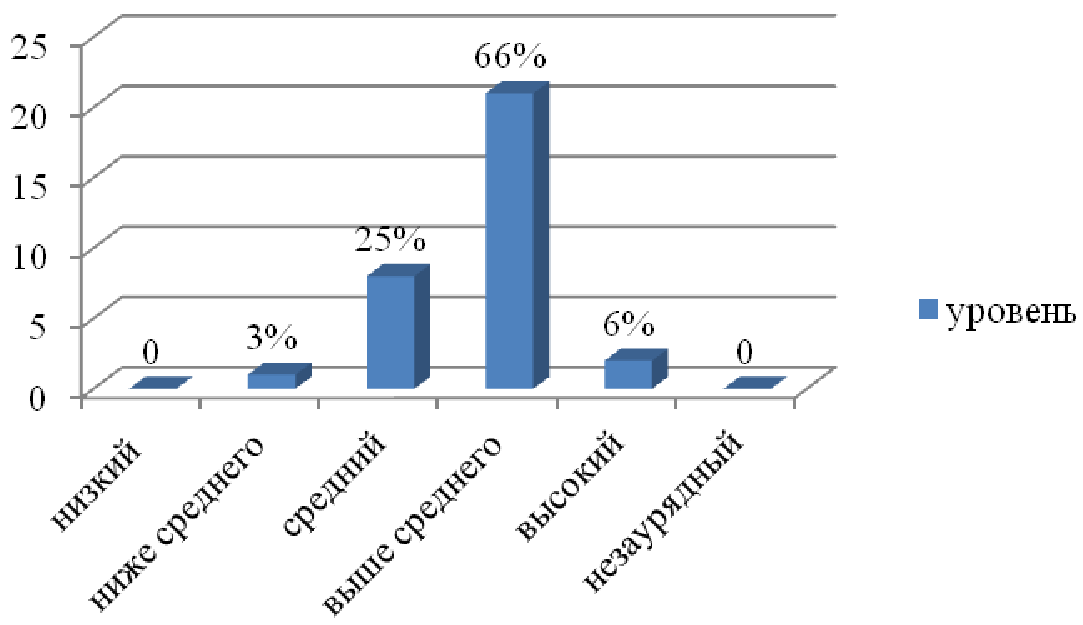

Рис. 6. Уровень интеллекта по результатам теста Равена у девушек из религиозных семей

\section{Интерпретация результатов}

Исследуя работу с пациентами, где попытка придерживаться религиозных воздержаний сталкивается с современной реальностью (сексуальная революция) и нарастающими потребностями, обусловленными физиологией, привела к невротическим и психическим отклонениям, включая нарушение пищевого поведения и сексуальные перверсии.

Полученные нами результаты подтверждают гипотезу о том, что основу образования анорексии подростков и молодых девушек составляет гипертрофированное чувство вины за сексуальные импульсы. Так, проблема нарушения пищевого поведения имеет вторичную выгоду, которая является удерживающим фактором. При достаточно активном либидо подростки часто не способны справиться с сексуальной энергией, которая вступает в конфликт с религиозной доктриной [31]. Мастурбировать, поддаваясь страстям, нельзя, а выйти замуж можно будет не скоро, что создает замкнутый круг проблемы для сексуально активного подростка. С переполняющими желаниями не всегда получается бороться, за счет чего имеют место срывы на мастурбацию [21]. Вслед за ней подросток испытывает чувство вины, зарекается этого больше не делать, но влечение не уходит и, несмотря на то что стыдно, мастурбация продолжается, накапливая вину в объеме, достаточном для уровня тяжелого невроза.

Когда человек фанатично старается придерживаться религиозных догм, тогда чувство вины за сексуальные желания и их удовлетворение возрастает и фиксируется, приобретая болезненный характер [31]. Если усилием воли продолжать сдерживать сексуальные импульсы, то это может привести к возникновению фантазий, связанных с сексуальными перверсиями, которые не все могут контролировать, и мысль превращается в действие. Обостряет проблему тот факт, что неизвестно, до какого времени придется себя сдерживать. После сексуальной революции полигамность не порицается и есть много искушающих факторов в открытом доступе. Если следовать вере, то сексуальные отношения возможны только в браке, а выбор партнера не гарантирует сексуальной совместимости, что может гарантировать несчастье в отношениях. Эта нестыковка по-настоящему хороших традиций с реальностью усугубляет внутренний конфликт и усиливает дискомфорт от сексуальных импульсов, которые должны доставлять удовольствие, находящееся в ловушке религиозного запрета. Правила легко выполнять не тогда, когда они призывают к добру и профилактике разврата, а тогда, когда их придерживается большинство. Особенно тяжело им следовать, когда представители морали, которые должны ее олицетворять, нередко сами не соблюдают того, к чему призывают. Либо придерживаются этого лишь 
потому, что для них это не является чем-то сложным. Например, легко говорить о важности воздержания, если имеются проблемы с потенцией или фригидность, ведь в таком случае неполноценность прикрывается духовностью. А если есть потенциал, который приходится сдерживать, он может проявить себя в любой момент.

Анорексия отчасти решает вопрос через ослабление сексуального влечения, так как нет влечения - нет проблемы. Ранние христиане использовали изнеможение тела скудной пищей, как предполагают, для подавления сексуальных и агрессивных импульсов [7].

Анорексия вызывает истощение организма, вследствие чего либидо становится меньше, а значит, снижается чувство вины.

Как только улавливается взаимосвязь между истощением организма и снижением либидо, формируется зависимость от истощения, которое дает освобождение от чувства вины. Начинается патологический процесс, который превращает анорексию в способ избавления от чувства вины за сексуальные желания и обеспечивает избавление от мастурбации, что позволяет удержать самооценку на безопасном уровне. При попытке нормализовать питание повышается уровень жизненных сил, а с ним и либидо, которое воспринимается подростком как порок, от которого надо избавляться любой ценой. Рассмотрение своих жизненных установок, в которые входят ценности и личностная идентификация с позиции веры, у некоторых подростков может приводить к занижению самооценки с элементами невозможности ее реабилитировать после множественных попыток укротить страсти при помощи инструментов, которые рекомендуют духовные наставники.

Еще одним фактором развития анорексии у подростков, подкрепленным результатами нашего исследования, является смещение агрессии, возникшей из-за когнитивного диссонанса. Так, девушки не могут сопоставить тот факт, что их родители, транслирующие набожность, добродетель и сексуальную сдержанность, оставили по неосторожности сексуальные игрушки на видном месте, что означало потакание низменным страстям, а также что допустили занятие сексом в момент ее присутствия дома. Здесь к чувству вины за сексуальность добавляется агрессия на родителей за двойные стандарты, которая пытается выйти через отвращение к ним, но это тоже грех, и отвращение смещается на продукты. Подросток отождествляет еду с родителями, ведь она преимущественно от них, и чем больше они ее предлагают, тем большее отвращение она вызывает. Получается, что к еде можно испытывать отвращение и непринятие, направленное на самом деле на родителей и получаемую от них информацию. Все это усиливается, если есть запрет на проявление агрессии на родителей в форме ограничения говорить на определенные темы, а сомнения в них приравниваются к неуважению, маловерию или греху.

Кроме того, равнодушие к еде приветствуется в христианстве и выделяет верующего в особый ряд просветления, где дух торжествует над плотью. Здесь можно предположить, что запускается еще один механизм, поддерживающий проблему, - религиозное тщеславие. Оно помогает отчасти совладать с чрезмерным и разрушительным импульсом агрессии на родителей за несоответствие слов и действий при помощи возвышения над ними в ранге веры. Это может объяснить появившуюся у некоторых девушек инициативность ходить в церковь, хотя раньше им приходилось ходить туда под давлением родителей или уклоняться под разным предлогом от регулярных посещений храма [16]. Таким образом, на наш взгляд, выявление молодыми людьми противоречий в постулатах веры родителей и их реального поведения является одной из причин возникновения анорексии.

Также можно отметить, что к последствиям внутреннего конфликта такого рода приводит не только высокий потенциал либидо, но и достаточно высокий интеллект. Активное мышление подростка пытается сопоставить религиозную доктрину с реальностью, но это не всегда возможно, одной только веры не хватает. Ведь к вере они приходят не сами, как это предполагает христианство, а уже оказались в ней по факту рождения. По мере взросления человек начинает все больше сопоставлять правила с реальностью и объяснять себе явления через религиозную доктрину, что часто идет вразрез с данными, которые появились в ходе научного прогресса и которые сложно не принимать во внимание. Молодые люди, обладающие меньшей поисковой активностью, с большей легкостью сглаживают нестыковки с помощью веры под действием авторитета в виде родителей или духовного наставника, которые, по мнению подростка, умнее, а значит, «им виднее».

\section{Обсуждение результатов}

Возникновение анорексии и в настоящий момент представляет научный интерес, но мало что известно о том, как концепция пищевой зависимости может способствовать пониманию явления ано- 
рексии [32]. Tran H., Poinsot P., Iceta S. провели исследование на выборке из 73 пациентов и показали, что распространенность пищевой зависимости в выборке составила $47 \%$. Она положительно коррелировала с подтипом переедания / очищения, более высокими уровнями депрессии, тревожности и большей психопатологией пищевого поведения. Пищевая зависимость не была связана с уровнем импульсивности. Связь между тяжестью пищевой зависимости и тяжестью анорексии была опосредована тяжестью переедания. Эти результаты сопоставимы с нашими.

По данным МКБ-10, психологической первопричиной анорексии является болезненная убежденность в собственной полноте, даже несмотря на низкий вес. В основе болезни лежит неотступное стремление похудеть, которое больные реализуют путем диеты, клизм и т. д. [15]. Наше исследование может указывать на то, что это слишком поверхностное предположение, которое сформировалось со слов пациентов. Данные высказывания о причинности своего недуга подростки формируют в виде рационализации, более или менее правдоподобного обоснования из-за непонимания действительных причин проблемы, которые находятся в бессознательном и не всегда могут быть осмыслены. Наше исследование доказывает влияние бессознательных факторов, которые влияют на появление и удержание негативного симптома.

В работе [31] у мусульманских студенток колледжей из Объединенных Арабских Эмиратов (ОАЭ) обнаружена положительная связь между религиозностью и симптомами расстройства пищевого поведения. Эти данные свидетельствуют о том, что повышенная религиозность молодых эмиратских женщин может представлять собой фактор уязвимости для расстройств пищевого поведения. В нашем исследовании также можно проследить данную закономерность.

Результаты различных исследований противоречивы, и остается неясным, с какими конкретными аспектами когнитивной гибкости пациенты с нервной анорексией могут бороться. Выявлено, что подростки с острой нервной анорексией не отличались от выздоровевших по выполнению нейрокогнитивных задач, несмотря на то что они сами сообщали о более низкой когнитивной гибкости [30]. В нашем исследовании показано, что, проявляя определенную когнитивную гибкость, пациенты могут преодолеть некоторые негативные установки и улучшить результаты коррекции пищевого поведения.

Диагностика тревожного расстройства в целом может прогнозировать повышенный риск нервной анорексии [28]. Наше исследование частично подтверждает факт того, что внутриличностные конфликты, порождаемые символическим смещением агрессии, чувством вины, сочетаемы с проявлениями анорексии.

\section{Выводы}

Анализируя полученные данные, можно сказать, что у девушек с анорексией из религиозных семей одной из причин появления и удержания проблемы являются не сами религиозные установки и основанный на них уклад семейной жизни, а внутренний конфликт, который возникает у подростка по ряду обстоятельств.

В первую очередь это непонимание, как совладать с проявлением своего либидо в рамках сохранения целомудренности. Во-вторых, влияние может оказать недостаток веры, имеющийся из-за того, что девушка к ней пришла не самостоятельно, проявив осознанность, а оказалась в этих условиях по воле родителей. Маловерие вызывает вопросы и недоверие к пропогандируемым нормам, которые транслируются в семье и религиозном сообществе, в связи со сложностью их применения в совеременных реалиях.

В качестве еще одного фактора внутриличностного конфликта можно выделить агрессию на родителей и ее смещение на продукты. Также замещенная агрессия может быть своего рода демонстрацией религиозного превосходства над своими родителями.

Таким образом, относительно решения поставленных задач нам в некоторой степени удалось выявить, что:

- девушки посредством отвращения к еде смещают отвращение к своим родителям, как результат «греховной» агрессии на них за двойные стандарты;

- анорексия, снижая либидо подростков и молодых девушек за счет истощения организма, способствует избавлению от чувства вины за возникающие у них сексуальные импульсы;

- обнаружено четыре критерия, которые могут обусловить возникновение анорексии у подростков из религиозных семей. 
1. Уровень интеллекта выше среднего (от 110 баллов по Равену). У девушек со склонностью к анализу и сопоставлению могут возникать сомнения в вере из-за невозможности соответствия ее постулатам в современной реальности. Достаточно высокий уровень критичного мышления в данном случае, на фоне неприсвоенных религиозных убеждений при небходимости их соблюдения, создает потенциал для невротизации и излишней агрессии, которые находят выход в самоистощении.

2. Гипертимная акцентуация [12], проявляющаяся в высокой сексуальной активности в сочетании с гипертрофированным чувством вины за эту же активность, выявленные в процессе структуированного психоаналитического интервью у $91 \%$ участниц исследования. Анорексия здесь является своего рода наказанием за возникающую сексуальность, с которой девушке не удается справиться, так как она воспринимает свои действия как порочные, либо она так себя карает за сам факт возникновения сексуальных сигналов и мыслей.

3. Демонстрация двойных стандартов родителями, вызывающая повышение уровня агрессии и обостренное чувство несправедливости, которые вымещаются на продукты. Девушка не может смириться с «греховностью» родителей, свидетелем которой она стала, и поэтому осуществляет бессознательный перенос своих негативных эмоций на еду.

4. Запрет на корректное и умеренное проявление агрессии в отношениях с значимыми объектами (родителями), который также обусловлен греховностью, провоцирует смещение подавляемой эмоции на символические объекты (продукты).

Вместе с тем еще раз отметим, что анорексия используется подростками для нейтрализации сексуальных импульсов, так как она способствует ослаблению всех витальных функций организма. Происходит нарушение гормональной системы, прекращается менструальный цикл. Анорексия проявляется как форма удовлетворения тщеславия, которое выступает для подавления агрессии в отношении родителей, девушка как бы возвышается над ними своей духовностью в контексте религиозной доктрины. Проведение психоаналитической терапии анорексии невозможно без временного выключения из процесса религиозного влияния некоторых подростков, так как без этого терапия слаба и не имеет в сознании подростка достаточных обоснований, что создает постоянные вопросы и внутриличностные конфликты.

\section{СПИСОК ЛИТЕРАТУРЫ}

1. Агапов В.С. Концепция Я и самореализация субъекта: проблемное поле научных исследований // Акмеология. 2012. № 3 (43). С. 26-31.

2. Атаманов В.М., Демичева Т.П., Ивашова Е.С. Клинико-психологические аспекты синдрома дефицита массы тела // Клиническая медицина. 2018. Т. 96, № 3. С. 262-266. DOI: 10.18821/0023-2149-2018-96-3-262-266

3. Балакирева Е.Е., Зверева Н.В., Якупова Л.П. Психологическая квалификация когнитивных нарушений при нервной анорексии у детей и подростков // Современная терапия в психиатрии и неврологии. 2014. № 1. C. $30-34$.

4. Барыльник Ю.Б., Филиппова Н.В., Антонова А.А., Бачило Е.В., Деева М.А., Сизов С.В., Гусева М.А. Диагностика и терапия расстройств пищевого поведения: мультидисциплинарный подход. Социальная и клиническая психиатрия. 2018. Т. 28, № 1. С. 50-57.

5. Винникотт Д. Игра и Реальность. М.: Институт общегуманитарных исследований, 2002. 288 с.

6. Власихина Н.В. Семейные отношения в религиозных семьях: современные исследования. Вектор науки ТГУ. 2017. № 1 (39) 45. С. 43-47.

7. Гумилев Л.Н. Конец и вновь начало. М.: Айрис-пресс: Рольф, 2000. С. 381.

8. Деремов Э.А. Протестанты на службе России // Протестанты на службе России: биографические очерки. СПб.: Изд-во РХГА, 2012. С. 7-11.

9. Клиническая психология: словарь / [Агарков С. Т. и др.]; ред. Н.Д. Творогова. М.: PerSe, 2007. 414 с.

10. Кляйн М. Зависть и благодарность. // Психоаналитические труды. Ижевск: Эрго, 2010. В 7 т. Т. 6. С. 32.

11. Леонова Е.Н. Социально-психологические типы пищевого поведения // Вестн. Удм. ун-та. Сер. Философия. Психология. Педагогика. 2017. Т. 27, вып. 2. С. 174-181.

12. Личко А.Е. Психопатии и акцентуации характера у подростков. Л.: Медицина. 1983. 255 с.

13. Микляева А.В., Румянцева П.В. Соотношение центральных и периферических компонентов в структуре социальной идентичности личности // Психологический журнал. 2011. № 5. С. 36-45.

14. Овчаренко В.И. Комплекс Эдипа // Англо-русский психоаналиический словарь. М., 2003.

15. Поведенческие синдромы, связанные с физиологическими нарушениями и физическими факторами (F50F59) // МКБ 10 - Международная классификация болезней 10-го пересмотра. URL: https://mkb-10.com/ index.php?pid $=4288$

16. Религия: за и против // ВЦИОМ. Пресс-выпуск. 2015. № 2888. 
17. Скугаревская Е.И., Петрович Т.П., Скугаревский О.А. Нервная анорексия у девочек-подростков: От дезадаптивного семейного воспитания до психосоматических последствий (описание клинических случаев) // Психиатрия, психотерапия и клиническая психология. 2011. № 2. С. 120-129.

18. Уфимцева Е.И. Особенности воцерковления в оценках православной молодежи // Социологические исследования. 2013. № 1. С. 127-135.

19. Файнгольд Л.И. Онанизм, его причины последствия и меры борьбы с ним. 4-е исправленное издание. Одесса: Книгоиздательство «Светоч», 1927. С. 2-3.

20. Фрейд 3. Введение в психоанализ: лекции. 2-е изд., перераб. М.: Изд-во СГУ, 2007. 522 с.

21. Фрейд 3. Основные психологические теории в психоанализе. Очерк истории психоанализа. СПб.: Алетейя, 1998. $250 \mathrm{c}$.

22. Фэйрберн Р. Избранные работы по психоанализу. М.: Канон+, 2020. 320 с.

23. Чумакова Д.М. Социально-психологические особенности семьи и религиозность родителей // Вестник Южно-Уральского государственного университета. 2010. Вып. 10, № 27 (203). С. 100-103.

24. Davis C., Bonder R., Chapter 10 - Genetics and epigenetics of food addiction / Eds: P. Cottone, V. Sabino, C.F. Moore, G.F. Koob. Compulsive Eating Behavior and Food Addiction. Academic Press, 2019. P. $293-327$. https://doi.org/10.1016/B978-0-12-816207-1.00010-X

25. Hirsch M. Körper und Nahrung als Objekte bei Anorexie und Bulimie / Praxis der Kinderpsychologie und Kinderpsychiatrie. 38 (1989) 3, S. 79-82. URL http://hdl.handle.net/20.500.11780/1905

26. La Barrie D., Raven A.H., Clendinen C., Jain J., Bradley B., Teer A.P., Michopoulos V., Vance L. A., Hinrichs R., Jovanovic T., Fani N. Maternal influences on binge eating behaviors in children // Psychiatry Research. 2021. Vol. 295, 113600. https://doi.org/10.1016/j.psychres.2020.113600

27. Lin Y.-W., Lin C.-Y., Strong C., Liu C.-H., Hsieh Y.-P., Lin Y.-C., Tsai M.-C. Psychological correlates of eating behavior in overweight/obese adolescents in Taiwan: Psychometric and correlation analysis of the Three-Factor Eating Questionnaire (TFEQ)-R21 // Pediatrics and Neonatology. https://doi.org/10.1016/j.pedneo.2020.08.006

28. Lloyd E.C., Haase A.M., Foster C., Verplanken B. A systematic review of studies probing longitudinal associations between anxiety and anorexia nervosa // Psychiatry Research. 2019. Vol. 276. Pp 175-185. https://doi.org/ 10.1016/ j.psychres.2019.05.010

29. Meadows A., Nolan L. J., Higgs S. Self-perceived food addiction: Prevalence, predictors, and prognosis // Appetite, 2017. Vol. 114. P. 282-298. https://doi.org/10.1016/j.appet.2017.03.051

30. Miles S., Gnatt I., Phillipou A., Nedeljkovic M. Cognitive flexibility in acute anorexia nervosa and after recovery: A systematic review // Clinical Psychology Review. 2020. Vol. 81, 101905. https://doi.org/10.1016/j.cpr.2020.101905

31. Thomas J., O'Hara L., Tahboub-Schulte S., Grey I., Chowdhury N. Holy anorexia: Eating disorders symptomatology and religiosity among Muslim women in the United Arab Emirates // Psychiatry Research. 2018. Vol. 260. P. 495-499. https://doi.org/10.1016/j.psychres.2017.11.082

32. Tran H., Poinsot P., Iceta S. Food addiction as a proxy for anorexia nervosa severity: new data based on the yale food addiction scale // Psychiatry Research. 2020. Vol. 293. 113472. https://doi.org/10.1016/j.psychres.2020.113472

33. Willenberg H. Die Polarität von Selbsterhaltung und Destruktion Das Symptom des willkurli chen Erbrechens unter dem Aspekt des Todestriebes // Forum Psychoanal. 1986. 2, s. 28-43. https://link.springer.com/chapter/10.1007/9783-642-73842-5 18

34. Wu Y.-K., Zimmer C, Munn-Chernoff M.A., Baker J.H. Association between food addiction and body dissatisfaction among college students: The mediating role of eating expectancies // Eating Behaviors. 2020. Vol. 39. 101441. https://doi.org/10.1016/j.eatbeh.2020.101441

Поступила в редакцию 21.04.2021

Цапенко Александр Владимирович, аспирант,

Клинический психолог-психотерапевт, руководитель Центра психологической безопасности

Донской государственный технический университет (ДГТУ)

344000, Россия, г. Ростов-на-Дону, пл. Гагарина, 1

E-mail: sirius-gipno@mail.ru

\section{A.V. Tsapenko}

\section{ANOREXIA AS A WAY TO SUPPRESS THE LIBIDO OF TEENAGERS}

DOI: $10.35634 / 2412-9550-2021-31-2-186-198$

This article examines the phenomenology of the secondary benefits of anorexia, namely, the use of this symptom to suppress libido in adolescents and young girls with hypertrophied internal and external religious prohibition on the part of parents to manifest their growing sexuality, due to physiology. The causes of anorexia are described in many scien- 
tific works, but the peculiarities of the influence of religious attitudes of parents on the formation of anorexia in adolescents are poorly disclosed. This article reveals the psychological mechanisms (replacing aggression and secondary benefits) that keep the problem and make it impossible to achieve a result in the treatment of this ailment. The article presents a sample of those who applied to a psychological center for help from parents of adolescents suffering from anorexia and at the same time having strong religious prejudices, which, in our opinion, affects the occurrence and retention of a negative symptom under certain circumstances. For successful therapy and prevention of anorexia, we have established what circumstances can contribute to the occurrence of anorexia in adolescents from families with a strong religious orientation. The key point in working with the girls with whom we managed to conduct psychoanalytic sessions was their temporary disconnection from their religious beliefs until a conscious choice in the future. This serves as a prerequisite for an effective solution to the problem, since the existing doubts about religion, what is good / bad, right / wrong, create a certain neurotic pressure and can lead to consequences such as anorexia.

Keywords: eating disorder, anorexia, oedipal conflict, adolescent libido, family religious attitudes, teenagers.

Received 21.04.2021

Tsapenko A.V., postgraduate student,

Clinical psychologist-psychotherapist, head of the Center for Psychological Security

Don State Technical University

Gagarina sq., 1, Rostov-on-Don, Russia, 344000

E-mail: sirius-gipno@mail.ru 